\author{
경운방법 및 비료종류가 호밀의 사초수량, 품질 및 생산비에 \\ 미치는 영향 \\ 김종덕 · 김수곤 · 권찬호 \\ 천안연암대학
}

\title{
Effect of Tillage System and Fertilizer Type on the Forage Yield, Quality, and Production Cost of Winter Rye
}

\author{
J. D. Kim, S. G. Kim and C. H. Kwon
}

Cheonan Yonam College

\begin{abstract}
This experiment was conducted to evaluate the effect of tillage system and fertilizer type on the forage yield, quality, and production cost of winter rye. This experiment was a $2 \times 2$ factorial arrangement for two tillage system (Tillage and No-tillage) and two fertilizer type (Chemical and Manure compost). There was no difference in dry matter (DM) content, TDN (total digestible nutrients) yield, and CP (crude protein) yield of rye, but the DM yield was significantly higher for rye in tillage compared to the no-tillage system. The use of chemical fertilizer type also showed significant increase in DM, TDN and CP yields compared to the use of manure compost as fertilizer. The $\mathrm{CP}$ content for rye was significantly higher in no-tillage compared to tillage system, but the type of fertilizer used has no significant effect. No significant effects were observed for NDF (neutral detergent fiber), ADF (acid detergent fiber), and TDN in tillage system and fertilizer type of rye. The total cost to prepare 1 ha is lower in no-tillage compared to tillage, but production cost in rye per kg of fresh, DM and TDN were almost the same as tillage system because of lower forage production. The total cost to prepare 1 ha with the use of chemical fertilizer was higher than using manure compost as fertilizer, however, the cost to produce $1 \mathrm{~kg}$ of fresh, DM and TDN were lower when using chemical as fertilizer because of higher yield. Based on the results of this study, tillage system and fertilizer type affected forage yield more than forage quality. Production cost per $1 \mathrm{~kg}$ of tillage was lower compared to no-tillage, and that of chemical was lower than manure because of higher forage yield.
\end{abstract}

(Key words : No-tillage, Tillage, Chemical fertilizer, Manure compost, Production cost)

$$
\text { I. 서 론 }
$$

우리나라 농업은 1960년대까지는 자급퇴비로 농사를 지었기 때문에 토양중 양분 축적으로 인한 문제는 관심의 대상이 되지 못하였다. 그 러나 계속 늘어나는 인구에 비하여 농경지 면 적이 협소하기 때문에 부족되는 식량난 해소를 위하여 매작기마다 최고의 수량을 생산하고자 고투입 농법에 의존해 온 결과 농업환경이 악
화되고 있다. 그 예로 화학비료 사용증가로 토 양의 산성화와 유기물 함량이 감소하는 등 지 력저하 및 지표수의 부영영화가 초래되고(김, 1995; Hussian 등, 1999; 김, 2002), 농약의 과다 사용에 의한 토양미생물과 천적이 감소하여 생 태계의 교란 및 농산물의 농약 잔류량이 증가 하고(김, 2002), 기계에 의한 과도한 경운으로 토양유실과 토양의 물리·화학성의 악화 등 많 은 문제점이 야기되고 있다(김, 2002). 따라서

Corresponding author : C. H. Kwon, Cheonan Yonam College, Sunghwan, Cheonan-Si 330-802, Korea Tel: 041-580-1015, Fax: 041-580-1249, E-mail: chkwon@yonam.ac.kr 
국민들은 환경보전과 식품 안전에 대한 관심이 더욱 높아지고 있어 이를 위해서는 농업환경의 보전, 농산물 생산의 지속성 유지 및 국민건강 을 위한 안전농산물을 생산하여 공급하는 체계 가 구축되어야 한다. 이를 위한 방법이 친환경 농업이며 장기적인 이익추구, 개발과 환경의 조 화, 자연 순환적 농업체계, 생태계 메커니즘을 활용하는 기술이다.

사료작물의 대량생산을 위한 관행의 농업은 토양침식을 조장할 뿐만아니라 생산성 증대를 위한 비료, 농약, 연료 등의 사용량 증가로 토 양의 물리 - 화학성의 악화와 환경오염을 증가 시키므로 친환경적이지 못하며, 노동력과 생산 비도 많이 소요되고 있는 실정이다. 그러므로 환경에 부정적인 영향을 최소화하고 경토의 유 실을 경감시키며 토양의 비옥도를 향상시킬 수 있는 농법이 개발되어야 할 것이다. 더 구체적 인 방법이 최소경운 및 무경운 기술의 개발, 축산분뇨의 자원화에 의한 유기질 비료의 사용 이라 할 수 있다(Moschler, 1972; 최 등, 1998; 김, 2002).

줄뿌림을 이용한 무경운 재배는 경운 작업을 생략하는 재배법으로 야산 개간지에서 관행과 동일한 수량을 얻을 수 있으며, 무경운 무비재 배는 관행 경운 파종에 비하여 콩의 수량이 $10 \%$ 이상 감소하였다(김 등, 1997). 무경운 재 배가 건조기에 토양수분 보존에 유리하고, 토 양침식 방지에 효과가 있으며, 잡초의 발생량 도 감소시키고, 노력, 유류 및 기계 등의 절감 으로 생산비를 낮추는 효과가 있다(유 등, 1997; 김 2002).
가축분뇨는 오랫동안 구비로서 지력증진에 공 헌해 왔다. 그러나 1970년대 이후 축산업이 다 두사육으로 전환됨에 따라 분뇨를 유용하게 이 용되지 못하고 그대로 방류하여 환경문제로 대 두되고 있다.

가축분뇨의 자원화 방법으로는 퇴비나 액상 분뇨화 하여 이용하는 방법이 있다. 가축분뇨 의 퇴비화는 각종 영양분을 동시에 함유하고 있어 작물에 대한 종합영양적인 효과를 나타낼 수 있다(신, 1999).

최근 호밀의 생산 기술 향상에 따른 단위 면 적당 수확량이 증가하였으며, 생산비가 경작방 법, 이용기술 및 규모에 따라 차익이 있음에도 불구하고 경작방법과 이용기술에 따른 생산비 를 조사한 시험은 거의 없는 실정이다(Rahman, 등 1996; Man 및 Wiktorsson, 2001; 권 등, 2003; 2004; 김 등, 2004).

따라서 본 시험은 화본과 사료작물인 호밀을 관행경운과 무경운으로 경운방법을 달리하고, 비 료원으로 화학비료와 퇴비를 시비하여 재배하 였을 때 사초생산량, 품질 및 생산비의 차이를 구명하기 위하여 실시하였다.

\section{ㅍ. 재료 및 방법}

본 시험은 2004년 10월 4일부터 2005년 4월 29까지 천안연암대학 실습농장의 사초시험포장 에서 수행하였으며, 시험장소의 토양은 옥수수 와 호밀을 재배해오던 포장으로 사료작물의 생 육에는 지장이 없는 토양이었다.

충남 천안의 온도 및 강수량은 Table 1 에서 보

Table 1. Mean temperature and precipitation at Cheonan, 2004 to 2005

\begin{tabular}{lccccc}
\hline \multirow{2}{*}{ Month } & \multicolumn{2}{c}{ Temperature $\left({ }^{\circ} \mathrm{C}\right)$} & & \multicolumn{2}{c}{ Precipitation (mm) } \\
\cline { 2 - 3 } \cline { 5 - 6 } & $2004-2005$ & Normal & & $2004-2005$ & Normal \\
\hline \hline October & 13.2 & 13.1 & & 4.5 & 58.5 \\
November & 8.2 & 6.1 & & 53.0 & 52.9 \\
December & 2.3 & -0.1 & & 33.0 & 29.1 \\
January & -2.0 & -3.0 & & 3.0 & 24.0 \\
February & -1.1 & -0.8 & & 29.8 & 27.7 \\
March & 4.5 & 4.4 & & 37.0 & 48.4 \\
April & 12.8 & 11.3 & & 53.7 & 78.9 \\
\hline Mean & 6.0 & 5.0 & Sum & 214.0 & 320.0 \\
\hline
\end{tabular}


는 바와 같다. 온도는 예년에 비하여 평균 $1.0^{\circ} \mathrm{C}$ 높았으며, 강수량은 예년보다 $106 \mathrm{~mm}$ 가 적었다.

본 시험은 $2 \times 2=4$ 요인시험으로 경운방법은 관행 경운과 무경운으로, 비료종류는 화학비료 와 퇴비를 두어 호밀의 사초 생산성, 품질 및 생산비를 비교하였다.

호밀의 품종은 'Koolgrazer'를 공시하였으며, 파종은 2004년 10월 4일에 ha당 $150 \mathrm{~kg}$ 을 $30 \mathrm{~cm}$ 줄 간격으로 줄뿌림하였다.

시험구 크기는 $6 \mathrm{~m}^{2}(1.5 \mathrm{~m} \times 4 \mathrm{~m})$ 로 하였다. 시 비량은 화학비료구는 질소, 인산 및 가리를 각 각 ha당 $150 \mathrm{~kg}, 100 \mathrm{~kg}$ 및 $100 \mathrm{~kg}$ 을 시비하였으 며, 퇴비구는 질소량으로 ha당 $300 \mathrm{~kg}$ 을 시용하 였다.

호밀의 수확은 2005년 4월 29일에 실시하였 다. 시험구의 수확은 6줄 중 중앙의 4 줄 $\left(4.8 \mathrm{~m}^{2}\right.$ $=1.2 \mathrm{~m} \times 4 \mathrm{~m})$ 을 수확하여 생초수량을 측정하였 다. 각 구별로 $500 \sim 800 \mathrm{~g}$ 의 시료를 채취한 다 음 $65^{\circ} \mathrm{C}$ 의 순환식 열풍건조기에 72 시간 이상 충분히 건조시킨 후 무게를 측정하여 건물률과 건물수량을 계산하였다. 각 시험에서 채취한 건 조시료는 Wiley Mill로 분쇄하여 20mesh 표준 체를 통과시킨 후 시료로 사용하였다.

NDF(neutral detergent fiber) 및 ADF(acid detergent fiber)는 Goering 및 Van Soest 방법(1970)으로
분석하였다. 조단백질 분석은 Kjeldahl법(Tecator, Kjeltec Auto Sampler System 1035 Analyzer)을 사용하여 AOAC 법(1990)으로 분석하였다.

$\mathrm{TDN}$ 수량은 $\mathrm{TDN}=88.9-(0.79 \times \mathrm{ADF} \%)$ 에 의하여 $\mathrm{TDN}$ 을 산출한 후 건물수량을 곱하여 구하였으며, 조단백질 수량은 단백질 함량에 건물수량을 곱하여 구하였다. RFV(relative feed value)는 $\mathrm{ADF}$ 와 $\mathrm{NDF}$ 가 건물소화율 및 섭취량 과 높은 상관관계를 가진다는 점에 근거하여 $\mathrm{ADF}$ 와 $\mathrm{NDF}$ 분석치에 의한 계산식으로 산출하 였다(Holland 등, 1990).

통계처리는 SAS(1999) package program(ver. 6.12)을 이용하여 분산분석을 실시하였다.

\section{III. 결과 및 고찰}

\section{1. 호밀의 생육특성과 사초수량}

호밀의 유식물 활력과 내한성은 경운방법과 비료종류에서 처리간에 차이가 없었다. 한편 녹체성은 경운방법에서는 차이가 없었으나, 비 료의 종류에서는 화학비료가 퇴비보다 녹체성 이 높았다. 신(1999)의 호밀의 액상분뇨 시험에 서 호밀의 녹체성은 액상분뇨를 화학비료의 질 소 대비 2배를 시용하였을 때도 화학비료와 액

Table 2. Effect of tillage system and fertilizer type on the agronomic characteristics and forage yield of rye

\begin{tabular}{|c|c|c|c|c|c|c|c|}
\hline \multirow{2}{*}{ Item } & \multicolumn{2}{|c|}{ Tillage system(T) } & \multicolumn{2}{|c|}{ Fertilizer type(F) } & \multicolumn{3}{|c|}{ P-value } \\
\hline & Tillage & No-tillage & Chemical & Manure & $\mathrm{T}$ & $\mathrm{F}$ & $\mathrm{T} \times \mathrm{F}$ \\
\hline Seedling vigor & 9 & 9 & 9 & 9 & & & \\
\hline Cold hardness & 9 & 9 & 9 & 9 & & & \\
\hline Stay green & 9 & 9 & 9 & 8 & & & \\
\hline Lodging resistance & 6 & 8 & 7 & 7 & & & \\
\hline Heading date & 26 April & 26 April & 26 April & 25 April & & & \\
\hline Plant height(cm) & 96 & 95 & 100 & 90 & & & \\
\hline Dry matter(\%) & 15.2 & 15.9 & 15.3 & 15.8 & NS & NS & NS \\
\hline DM yield(kg ha $\left.{ }^{-1}\right)$ & 8,207 & 7,357 & 8,427 & 7,136 & 0.0175 & 0.0019 & 0.0417 \\
\hline TDN yield(kg ha $\left.{ }^{-1}\right)$ & 4,846 & 4,370 & 4,997 & 4,219 & NS & 0.0145 & NS \\
\hline CP yield(kg ha $\left.{ }^{-1}\right)$ & 1,343 & 1,315 & 1,462 & 1,195 & NS & 0.0020 & NS \\
\hline
\end{tabular}

Seedling vigor, cold hardness, stay green, lodging resistance : $9=$ good, $1=$ poor.

$\mathrm{DM}=$ dry matter, $\mathrm{TDN}=$ total digestible nutrients, $\mathrm{CP}=$ crude protein . 
상분뇨간에 녹체성의 차이가 없었다고 하였다. 본 시험에서 질소대비 2 배를 시비한 퇴비가 화 학비료보다 녹체성이 낮은 것은 퇴비는 전량 기비로 시용한 반면 화학비료는 기비와 추비로 나누어 시용하여 수확시기 화학비료구의 녹체 성이 높은 것으로 판단된다.

호밀의 내도복성은 비료의 종류에서는 7점으 로 낮았으나 처리간에 차이는 없었다. 신(1999) 의 화학비료와 돈분 및 우분 액상분뇨 시험에 서도 처리간에 내도복성의 차이가 없었다고 하 여 본 시험과 동일하였다.

한편 경운방법에서는 경운과 무경운이 각각 6점과 8점으로 무경운에서 호밀이 덜 도복되었 다. 김(1994)과 김(2002)의 옥수수 시험과 박 등 (1996)의 벼 시험에서 경운방법간에 토양의 뿌 리분포의 비교에서 무경운은 경운에 비하여 뿌 리 량이 적고 대부분 표층에 많이 분포한다고 하였으며, 이러한 뿌리분포는 도복과 관련이 있다고 하였다. 본 시험은 토양 중의 뿌리분포 와 량을 측정하지 않았으나 무경운이 경운보다 도복에 강한 것은 뿌리의 영향보다는 지상부의 수량이 적어 바람에 영향을 적게 받은 것으로 판단되었다.

호밀의 초장은 경운방법에서는 큰 차이가 없 었다. 김(1994)의 관행(경운 +로터리)과 로터리 의 비교에서 경운을 한 관행이 로터리보다 옥 수수의 초장과 착수고가 높았다. Raimbault 등 (1991)은 경운 옥수수가 무경운보다 초장이 컸 으나 건조기에는 일반적으로 경운이 작았다고 하였다. 김(2002)의 옥수수 시험에서는 무경운 과 경운 간 초장의 차이가 없었다고 하여 본 시험의 결과를 뒷받침하였다.
한편 비료종류에서는 화학비료와 퇴비가 각 각 $100 \mathrm{~cm}$ 와 $90 \mathrm{~cm}$ 로 화학비료가 $10 \mathrm{~cm}$ 높았다. 신(1999)의 시험에서도 화학비료가 돈분 및 우 분액비에 비하여 호밀의 초장이 $9 \mathrm{~cm}$ 높아 본 시험과 같았다. 비료종류에서 화학비료가 퇴비 보다 초장이 높은 것은 화학비료가 퇴비보다 속효성 비료이기 때문인 것으로 여겨진다.

호밀의 출수기는 경운방법에서 처리간에 차 이가 없었으나, 비료종류에서는 퇴비가 화학비 료가 1일 빨랐다. Raimbault(1991)은 옥수수의 출사소요일수의 비교에서 경운이 무경운보다 1 일 늦었다고 하였으며, 김(2002)의 시험에서도 경운 옥수수가 무경운보다 출사기와 출수기가 $1 \sim 2$ 일 빠르다고 하여 본 시험과는 차이가 있 었다. 이는 옥수수의 생육기간 3 4개월인 반 면, 호밀의 생육기간은 6 개월이 소요되기 때문 에 경운방법이 출수기에 영향을 덜 미친 것으 로 판단되었다.

호밀의 수확시 건물률은 경운방법에서 경운 과 무경운이 각각 $15.2 \%$ 및 $15.9 \%$ 로 무경운이 높았다. 김(1994)의 관행(경운+로터리)과 로터 리의 비교에서 경운이 무경운보다 옥수수의 건 물률이 낮아 본 시험과 같은 경향이었다.

한편 비료의 종류에서는 화학비료와 퇴비가 각각 $15.3 \%$ 및 $15.8 \%$ 로 퇴비가 화학비료보다 높았으나 통계적인 유의성은 없었다.

호밀의 건물수량은 경운방법에서 경운과 무 경운이 각각 $\mathrm{ha}$ 당 $8,207 \mathrm{~kg}$ 및 $7,357 \mathrm{~kg}$ 으로 경 운이 무경운보다 $850 \mathrm{~kg}$ 많았다 $(\mathrm{P}<0.05)$. 비료의 종류에서는 화학비료와 퇴비가 각각 ha당 8,427 $\mathrm{kg}$ 및 7,136 kg로 화학비료가 퇴비보다 $1,291 \mathrm{~kg}$ 많았다 $(\mathrm{P}<0.05)$.

Table 3. Effect of tillage system and fertilizer type on the forage quality of rye

\begin{tabular}{|c|c|c|c|c|c|c|c|}
\hline \multirow{2}{*}{ Item } & \multicolumn{2}{|c|}{ Tillage system(T) } & \multicolumn{2}{|c|}{ Fertilizer type(F) } & \multicolumn{3}{|c|}{ P-value } \\
\hline & Tillage & No-tillage & Chemical & Manure & $\mathrm{T}$ & $\mathrm{F}$ & $\mathrm{T} \times \mathrm{F}$ \\
\hline Crude protein(\%) & 16.4 & 17.9 & 17.4 & 16.9 & 0.0452 & NS & NS \\
\hline $\mathrm{ADF}(\%)$ & 38.4 & 37.9 & 38.1 & 38.2 & NS & NS & NS \\
\hline NDF(\%) & 64.4 & 61.9 & 63.5 & 62.9 & NS & NS & NS \\
\hline TDN(\%) & 59.0 & 59.3 & 59.2 & 59.1 & NS & NS & NS \\
\hline RFV & 85 & 90 & 87 & 88 & NS & NS & NS \\
\hline
\end{tabular}

$\mathrm{ADF}=$ acid detergent fiber, $\mathrm{NDF}=$ neutral detergent fiber, $\mathrm{TDN}=$ total digestible nutrients, $\mathrm{RFV}=$ relative feed value. 
호밀의 TDN 및 조단백질 수량도 건물수량과 마찬가지로 경운방법에서는 경운이 무경운보다 많았으며 $(\mathrm{P}>0.05)$, 비료의 종류에서는 화학비료 가 퇴비보다 수량이 많았다 $(\mathrm{P}<0.05)$.

김(1994)의 관행(경운 + 로터리)과 로터리의 비교 에서 옥수수 건물수량과 TDN 수량의 비교에서 관행과 로터리 처리간에 차이가 없다고 하였다.

그러나 Jones 등(1968)과 Elkine 등(1979)에 따 르면 무경운 재배는 경운재배보다 옥수수의 수 량이 적었다고 하였으며, Triplett 등(1968)도 옥 수수의 수량이 많거나 비슷하다고 하였으며, 건조기일수록 경운과 무경운의 차이는 많았다 고 하였다. 따라서 가을에 파종하여 이듬해 봄 에 수확하는 월년생 사료작물은 우리나라에서 강수량이 가장 적은 시기이므로 무경운에 의하 여 수분부족을 해결함으로서 사초수량을 향상 시킬 수 있는 기술로 판단되었다.

화학비료와 퇴비의 비교에서 화학비료 시용 에서 수량이 많은 이유는 퇴비의 휘산에 의한 대기 중 손실과 화학비료의 추비가 화학비료 의 수량의 향상에 영향을 준 것으로 판단된 다. Thompson 등(1987)의 보고가 액상분뇨이긴 하지만 암모니아의 휘산에 의한 질소 손실이 겨울에는 ha당 $53 \mathrm{~kg}$, 봄에는 $77 \mathrm{~kg}$ 이었다고 하
였다. 육 등(1997)의 시험에서 액상분뇨의 시용 시기를 가을, 봄, 가을과 봄 분시의 비교에서 분시가 다른 처리구보다 호밀의 수량이 많았 다. 따라서 화학비료가 퇴비보다 호밀의 사초 수량에 많은 영향을 미친 것으로 판단되었다.

\section{2. 호밀의 사초품질}

호밀의 조단백질 함량은 경운과 무경운이 각 각 $16.4 \%$ 및 $17.9 \%$ 로 무경운이 경운보다 많았 다 $(\mathrm{P}<0.05)$. 비료의 종류에서는 화학비료와 퇴 비가 각각 $17.4 \%$ 및 $16.9 \%$ 로 화학비료보다 많 았으나 통계적인 유의성은 없었다. 화학비료가 퇴비보다 단백질 함량이 많은 것은 앞서 언급 한 바와 같이 화학비료의 분시가 호밀의 단백 질 함량에 영향을 미친 것으로 판단되었다. 신 (1999)의 시험에도 화학비료가 $\mathrm{N}$ 함량 2 배로 돈분 및 우분액비를 2 배 시비한 처리구 보다 높았다.

한편 $\mathrm{ADF}$ 및 $\mathrm{NDF}$ 함량에서는 경운이 무경 운보다 많았으나 비료의 종류에서는 $\mathrm{ADF}$ 와 $\mathrm{NDF}$ 함량이 상반되었으며 처리간의 유의적인 차이 도 없었다. 신(1999)의 시험에서 호밀의 $\mathrm{ADF}$ 및 $\mathrm{NDF}$ 함량은 화학비료가 돈분액비보다 높았으

Table 4. Effect of tillage system and fertilizer type on the production cost of rye

\begin{tabular}{lrrrrr}
\hline \multirow{2}{*}{ Items of cost, Won(\%) } & \multicolumn{2}{c}{ Tillage system } & & \multicolumn{2}{c}{ Fertilizer type } \\
\cline { 2 - 3 } \cline { 5 - 6 } Land cost & \multicolumn{1}{c}{ Tillage } & No-tillage & & Chemical & Manure \\
\hline \hline Seed cost & $595,500(34.3)$ & $595,500(38.1)$ & & $595,500(35.8)$ & $595,500(36.4)$ \\
Fertilizer cost & $110,250(6.3)$ & $110,250(7.1)$ & & $110,250(6.6)$ & $110,250(6.7)$ \\
Agrochemical cost & $212,957(12.3)$ & $212,957(13.6)$ & & $225,913(12.3)$ & $200,000(12.2)$ \\
Human labor cost & $0(0.0)$ & $0(0.0)$ & & $0(0.0)$ & $0(0.0)$ \\
Materials cost & $210,000(12.1)$ & $140,000(9.0)$ & & $175,000(12.1)$ & $175,000(10.7)$ \\
Depreciation cost & $250,000(14.4)$ & $250,000(16.0)$ & & $250,000(14.4)$ & $250,000(15.3)$ \\
Maintain \& repair cost & $110,000(6.3)$ & $85,000(5.4)$ & & $97,500(6.3)$ & $97,500(6.0)$ \\
Fuel cost & $50,000(2.9)$ & $45,000(2.9)$ & & $40,000(2.9)$ & $40,000(2.9)$ \\
The others & $148,900(8.6)$ & $74,450(4.8)$ & & $11,675(8.6)$ & $11,675(6.8)$ \\
\hline Total cost of production/ha & $1,737,607$ & $1,563,157$ & & $1,663,338$ & $1,637,425$ \\
Cost of production/Fresh kg & 32 & 34 & & 30 & 36 \\
Cost of production/DM kg & 212 & & & $30,000(2.9)$ & $50,000(3.1)$ \\
Cost of production/TDN kg & 359 & 364 & & 332 & 367 \\
\hline
\end{tabular}

$\mathrm{DM}=$ dry amtter, $\mathrm{TDN}=$ total digestible nutrients. 
나 우분액비와는 차이가 없었다.

호밀의 TDN 및 상대사료가치는 무경운이 경 운보다 많았으며, 비료의 종류에서는 화학비료 가 퇴비보다 많았으나 통계적인 유의성은 없었 다. 신(1999)의 시험에도 화학비료와 돈분액비 및 우분액비 간에 상대사료가치의 차이가 없어 본시험과 같은 경향을 보였다.

경운방법 및 비료종류가 호밀의 품질에 미치 는 영향에서는 조단백질 함량을 제외하고는 처 리간에 차이가 없었다.

\section{3. 호밀의 생산비}

경운방법에 따른 호밀의 생산비는 Table 4에서 보는 바와 같다. 경운의 $1 \mathrm{ha}$ 당 생산비는 $1,737,607$ 원으로 무경운의 $1,563,157$ 원보다 174,450 원이 많았다. 경운이 무경운보다 면적당 생산비가 많은 이유는 인건비, 감가상각비, 유지수선비 및 유류비가 많이 소요되었기 때문이다.

한편 호밀 생초 $1 \mathrm{~kg}$ 당 생산비는 경운과 무 경운이 각각 32 원과 34 원으로 무경운이 2원 많 았다. 호밀의 건물 $1 \mathrm{~kg}$ 당 생산비는 경운과 무 경운이 각각 212원과 216원 이였으며, TDN 1 $\mathrm{kg}$ 당 생산비는 경운 및 무경운이 각각 359원 및 364원으로 무경운이 경운보다 많았다. 경운 이 단위면적당 생산비가 많음에도 불구하고 생 초, 건물 및 $\mathrm{TDN} \mathrm{kg}$ 당 생산비가 적은 이유는 경운이 무경운보다 생초, 건물 및 $\mathrm{TDN}$ 수량이 많기 때문이다.

본 시험에서 호밀의 원물 $1 \mathrm{~kg}$ 당 생산비는 30 원에서 36원, 건물 $1 \mathrm{~kg}$ 당 생산비는 197원에서 231원, TDN $1 \mathrm{~kg}$ 당 생산비는 332원에서 390원 으로 원물보다 건물과 $\mathrm{TDN}$ 에서 처리간에 생산 비의 차이가 많았다. 이러한 차이는 단위면적 당 생산량과 품질에 기인한 것으로 판단되어 재배방법의 변화로 생산비의 절감이 가능할 것 으로 판단되었다. 권 등(2003; 2004)의 2년간 옥수수의 생산비 조사에도 옥수수의 생산비가 농가에 따라 크게 차이가 있었으며, 이는 임대 료, 용역비 등과 함께 단위면적당 생산량이 가 장 큰 영향을 미쳤다고 하였다.

그러나 무경운이 경운보다 $\mathrm{kg}$ 당 생산비는 많
이 소요되나 우리나라와 같이 같은 포장에서 2 모작을 할 경우 수확과 파종상 준비 및 파종까 지 시간을 최대한 단축시킬 수 있는 무경운 파 종기술이 필요하다(Adams 등, 1973; Naser, 1977; Hargrove 등, 1982).

비료종류에서는 화학비료의 $1 \mathrm{ha}$ 당 생산비는 $1,663,338$ 원으로 퇴비의 $1,637,425$ 원 보다 25,913 원이 많았다. 이는 화학비료가 퇴비보다 비용 이 많이 소요되었기 때문이다.

한편 호밀 생초 $1 \mathrm{~kg}$ 당 생산비는 화학비료와 퇴비가 각각 30원과 36원으로 화학비료가 6원 적었으며, 건물 $1 \mathrm{~kg}$ 당 생산비는 화학비료와 퇴 비가 각각 197원과 231원으로 화학비료가 34원 적고, $\mathrm{TDN} 1 \mathrm{~kg}$ 당 생산비는 화학비료와 퇴비가 각각 332원 및 390원으로 화학비료가 퇴비보다 58 원 적어 생초보다 건물 및 TDN 수량에서 생 산비의 차이가 많았다. 화학비료가 면적당 생 산비가 많음에도 불구하고 생초, 건물 및 $\mathrm{TDN}$ $\mathrm{kg}$ 당 생산비가 적은 이유는 화학비료가 퇴비보 다 생초, 건물 및 TDN 수량이 많기 때문이다.

호밀의 생산비 중에서 가장 큰 비중을 차지 하는 것은 지대(임대료)였으며, 다음은 재료비, 인건비, 비료비 등이 많이 차지하였다. 그러나 이보다도 생산비에 가장 많은 영향을 미친 것 은 호밀의 생산량과 품질이었다. 즉, 재배방법 에 따라 호밀의 생산량과 품질이 다양하였으 며, 이것이 호밀의 생산비에 영향을 미쳤다. 따 라서 호밀의 생산비를 줄이기 위한 방법으로 호밀의 생산량과 품질을 높이는 재배기술의 개 발과 보급이 중요한 요인으로 평가되었다.

이상의 호밀 결과를 볼 때 호밀의 사초수량 은 경운이 무경운보다 많았으나, 사초품질은 무경운의 조단백질 함량이 경운보다 많은 것을 제외하고는 처리간에 차이가 없었다. 한편 비 료종류에서는 화학비료의 사초수량이 퇴비보다 많았으나 사초의 품질은 처리간에 차이가 없었 다. 호밀의 생산비에서는 무경운이 경운보다 적 었으며, 비료의 종류에서는 퇴비가 화학비료보 다 $\mathrm{kg}$ 당 생산비가 많았다. 따라서 호밀의 사초 수량과 조단백질 함량을 증가시키기 재배방법 으로 무경운 재배를 추천할 수 있다. 그리고 축분퇴비를 호밀에 시용할 경우에 호밀의 사초 
수량은 화학비료에 비하여 $15 \%$ 적어 호밀의 $\mathrm{kg}$ 생산비도 퇴비가 많았다. 따라서 농가에서 호밀을 생산할 경우에는 사초수량, 사초 품질 뿐만아니라 경제성도 고려하여야 한다. 그리고 유기축산을 위하여 호밀을 생산하기 위한 재배 방법으로 무경운을 추천할 수 있으나 퇴비의 이용은 경제적인 손실을 감수해야 할 것이다.

$$
\text { IV. 요 약 }
$$

밭에서 호밀에 경운방법과 비료종류를 달리 하였을 때 사초의 생산성, 품질 및 생산비를 비 교하기 위하여 수행하였다. 본 시험은 $2 \times 2=4$ 요인 시험으로 경운방법은 경운과 무경운을 두 었으며, 비료종류는 화학비료와 퇴비를 두었다. 호밀의 건물률, $\mathrm{TDN}$ 수량 및 $\mathrm{CP}$ 수량은 처리 간에 유의적인 차이가 없었으나, 경운의 건물 수량은 무경운보다 많았다 $(\mathrm{P}<0.01)$. 한편 비료 종류에서는 화학비료의 건물수량, $\mathrm{TDN}$ 수량 및 $\mathrm{CP}$ 수량이 퇴비보다 많았다. 호밀의 조단백질 함량은 무경운이 경운보다 높았으나 $((\mathrm{P}<0.05)$, 비료의 종류에서는 처리간에 유의적인 차이가 없었다. 호밀의 $\mathrm{NDF}, \mathrm{ADF}$ 및 $\mathrm{TDN}$ 함량은 처 리간에 유의적인 차이가 없었다. 호밀의 면적 당 생산비는 경운이 무경운보다 많았으나, 원 물, 건물 및 TDN $1 \mathrm{~kg}$ 당 생산비는 무경운이 많 았다. 한편 비료의 종류에서는 화학비료의 면 적당 생산비가 퇴비보다 많았으나 원물, 건물 및 $\mathrm{TDN} 1 \mathrm{~kg}$ 당 생산비는 화학비료가 적었다. 이는 경운과 화학비료가 무경운과 퇴비보다 사 초수량이 많았기 때문이다. 이상의 시험결과를 볼 때 경운방법과 비료종류는 호밀의 품질보다 사초수량에 많은 영향을 미쳤다. 경운과 화학 비료가 무경운과 퇴비보다 호밀의 $1 \mathrm{~kg}$ 당 생산 비가 적었는데 이는 경운과 화학비료의 사초수 량이 다른 처리구보다 많았기 때문이다.

$$
\mathrm{V} \text {. 사 사 }
$$

본 연구는 농림부 농림기술관리센터의 연구 비 지원의 일부에 의해 수행된 것으로, 이에 감사를 드립니다.

\section{VI. 인 용 문 헌}

1. Adams, W. E., Morris, H. D., Giddens, Joel, Dawson, R. N. and Landale, G. W. 1973. Tillage and fertilization of corn grown on lespedeza sod. Agron. J. 65:653-655.

2. AOAC. 1990. Official Method of Analysis(15th ed.). Association of Official Analytical Chemists. Washington, DC.

3. Elkins, D. M., Vandeveter, J. W., Kapusta, G. and Anderson, M. R. 1979. No-tillage maize production in chemically suppressed grass sod. Agron. J. 71(1):101-105.

4. Goering, H. L. and Van Soest, P. J. 1970. Forage Fiber Analysis. Agr. Handbook No. 379. USDA.

5. Hargrove, W. L., Reid, J. T., Youchton, J. T. and Gallaher, R. N. 1982. Influence of tillage practices on the fertility status of an acid soil double cropped to wheat and soybean. Agron. J. 74:684-687.

6. Holland, C., Kezar, W., Kautz, W. P., Lazowski, E. J., Mahanna, W. C. and Reinhart, R. 1990. The Pioneer Forage Manual-A Nutritional Guide. Pioneer Hi-Bred Int. Inc., Des Moines, IA.

7. Hussain, I., Olson, K. R. and Ebelhar, S. A. 1999. Long-term tillage effects on soil chemical properties and organic matter fraction. Soil Sci. Soc. Am. J. 63:1335-1341.

8. Jones, J. N., Moody, J. E., Shear, G. M., Moschler, W. W. and Lillard, J. H. 1968. The no-tillage system for corn(Zea mays L.). Agron. J. 60(1):17-20.

9. Moschler, W. W., Shear, G. M., Martens, D. C., Jones, G. D. and Wilmouth, R. R. 1972. Comparative yield and fertilizer efficiency of no-tillage and conventionally tiller corn. Agron. J. 64(2):229-231.

10. Man, N. V. and Wiktorsson, H. 2001. The effect of replacing grass with urea treated fresh rice straw in dairy cow diet. Asian-Aust. 
J. Anim. Sci. 14(8):1090-1097.

11. Naser, H. G. 1977. Multiple cropping in some countries of the middle east: In multiple cropping. Am. Soc. of Agron. Spec. Pub. No. 27. Am. Soc. of Agron. Madison, pp. 117-128.

12. Rahman, S. M. A., Begum, J. and Alam, J. 1996. Fodder production at savar dairy farm: An economic analysis. Asian-Aust. J. Anim. Sci. 9(4):411-420.

13. Raimbault, B. A., Vyn, T. J. and Tollenaar, M. 1991. Corn response to rye cover crop, tillage methods, and planter options. Agron. J. 83:287-290.

14. SAS Institute, Inc. 1999. SAS user's guide : Statistics. SAS Inst., Inc., Cary, NC.

15. Thompson, R. B., Ryde, J. C. and Lockyer, D. R. 1987. Fate of nitrogen in cattle slurry following surface application or injection to grassland. J. Soil Sci. 38:689-700.

16. Triplett, G. B., Jr., Van Doren, D. M. and Schmidt, B. L. 1968. Effect of corn(Zea mays L.) stover mulch on no-tillage corn yield and water infiltration. Agron. J. 60(2): 236-239.

17. 권찬호, 주종철, 김종덕, 최태일, 김정철, 김 경환. 2003. 중북부 지방의 옥수수 생산량 조사연구. 천안연암대학. 서울우유협동조합 연구보고서.

18. 권찬호, 김종덕, 김수곤, 고석종, 최태일. 2004. 중북부 지방의 옥수수 생산량 조사 및 사일리지용 수수의 생산 및 사일리지 제조 방법에 대한 연구. 천안연암대학. 서울우유 협동조합 연구보고서.
19. 김석동, 유용환, 이석하, 김욱한. 1997. 콩 무경운 재배기술 확립시험. 농촌진흥청 작 물시험장. 시험연구보고서 pp. 42-44.

20. 김원호. 1994. 작물의 잔주와 그 관리가 사 일리지용 옥수수의 생장, 수량 및 사료가치 에 미치는 영향. 서울대학교 박사학위 논 문.

21. 김원호, 서성, 조영무, 이종경, 이광명, 최석 승. 2004. 총체보리와 곡식보리 재배의 소 득 비교. 한초지 24(특별호):182-183.

22. 김은석. 2002. 친환경 풋찰옥수수 생산을 위한 경운방법 및 두과 피복작물재배에 관 한 연구. 경상대학교 박사학위 논문.

23. 박홍규, 김상수, 백남현, 석순종, 박건호, 이 선룡. 1996. 벼 무경운 재배시 재배양식에 따른 생육 및 수량. 한작지 41(4):420-428.

24. 신동은. 1999. 축종별 액상분뇨와 질소(N) 시용량이 양질조사료의 수량, 사료가치 및 토양특성에 미치는 영향. 서울대학교 박사 학위 논문.

25. 유철현, 신복우, 정지호, 한상수, 김성조, 한 성수. 1997. 경운방법에 따른 논토양의 이 화학성 변화. 한국토양비료학회지 30(2):140145.

26. 육완방, 차용복, 금종성, 이종민, 한영근. 1997. 액상구비의 시용시기와 시용수준이 호 밀의 생산성에 미치는 영향. 한초지 10(2):8488.

27. 최진룡, 김정부, 조영순. 1998. 한반도에서 지 속농업의 실천방안. 지속적 벼 생산체계 개 발을 중심으로. 경상대학교 개교50주년 심포 지움: 228-312.

(접수일자 : 2005. 10. 4. / 채택일자 : 2006. 2. 14.) 